\title{
The Swedish Plans to Acquire Nuclear Weapons, 1945-1968: An Analysis of the Technical Preparations
}

\section{Thomas Jonter}

\author{
Department of Economic History, Stockholm University, Stockholm, Sweden
}

Swedish nuclear-weapons plans are analyzed during the period 1945-1968. By the end of this period, Sweden had in place a nuclear program capable of producing nuclear weapons within a few years. But for a combination of reasons-among them rising public opposition to nuclear weapons, tension between civilian nuclear power goals and the goal of maintaining freedom of action with respect to nuclear weapons, the US policy to discourage the Swedes from building the bomb, and strengthening of international nonproliferation norms - the program was abandoned in 1968 when Sweden joined the Non-proliferation Treaty as a non-weapon state.

\section{INTRODUCTION}

Swedish nuclear plans have generated rumors over the years, catching the attention of both national and international media from time to time. ${ }^{1}$ Questions about the status of these plans have been raised ever since the Swedish parliament decided to shelve the nuclear option with the signing of the Nonproliferation Treaty (NPT) in 1968. Why was the nuclear program terminated? How advanced were Swedish technological preparations for the production of nuclear weapons? ${ }^{2}$ Can the Swedish case serve as a convincing example for other nations with nuclear weapons ambition to abandon them?

This article recounts, in broad terms, the history of nuclear weapons research in Sweden, its aims and results regarding technological preparations. How was research organized? With which companies and research institutions

Received 3 September 2008; accepted 12 February 2010.

Address correspondence to Thomas Jonter, Department of Economic History, Stockholm University 106 91, Stockholm, Sweden. E-mail: thomas.jonter@ekohist.su.se 
in Sweden and abroad did the responsible organization, the Swedish National Defence Research Establishment (FOA), collaborate? The focus in this article is on the technical aspects of the Swedish nuclear plans, even though other aspects of a possible Swedish nuclear weapons acquisition are touched upon.

\section{SWEDISH NUCLEAR WEAPONS PLANS, THE EARLY YEARS: 1945-1952}

Sweden's nuclear-weapons research began in 1945, shortly after the first atomic bombs fell over Japan. The mission to look into the new weapon of mass destruction went to the newly established FOA. On 17 August 1945, the Supreme Commander's representative on the Council of FOA, Torsten Schmidt, requested "an account of what might currently be known about the atomic bomb." 3 The main aim of the research initiated at that time was to find out how Sweden could best protect itself against a nuclear weapon attack. However, from the outset, FOA was also commissioned to investigate the possibilities of manufacturing an atomic bomb. Leading military and the Swedish political elite maintained that nuclear weapons would be necessary for deterring the Soviet Union from attacking Sweden and for upholding Sweden's policy of political nonalignment. For example, in his memoirs the Swedish Social Democratic Prime Minister, Tage Erlander, writes that for several years in the late 1940 s and early 1950 s, he supported a nuclear weapons program for Sweden. ${ }^{4}$

In November 1945, the Atomic Committee (Atomkommittén, AC) was founded. AC was an advisory committee of experts with the mission to work out plans and prioritize alternative pathways for the development of civilian nuclear energy. The committee was appointed by the government and its members represented military, industrial, political and academic interests. The initiative to establish AC came from the military, which suggests that nuclear-weapons plans played an important role in the establishment of civilian nuclear-energy research. Furthermore, five of the Atomic Committee's members were also on the board for FOA. ${ }^{5}$ Academic research institutions had several representatives on the AC, among them the Nobel Prize winners in physics Manne Siegbahn (he received the prize in 1924) and Hannes Alfvén (he received the prize in 1970). The industry and military were represented by the director-general for the Swedish telephone company, Håkan Sterky (he was also chairman of FOA). The technical director at the Swedish company ASEA (Allmänna Svenska Elektriska AB), Ragnar Liljeblad, represented industry. Chairman of the AC was county governor Malte Jacobsson, a politician from the Social Democratic party and professor of philosophy, and the secretary, Gösta Funke, was a young physicist. ${ }^{6}$

One of the first and more important tasks that $\mathrm{AC}$ gave FOA was to acquire uranium. To extract uranium from primarily Kolm-type shale in Sweden was the basis of the plan for self-sufficiency that Sweden decided to pursue early on. 
To attain self-sufficiency in nuclear matters was an obvious aim for Swedish politicians and researchers shortly after the Second World War. For this reason, Sweden chose a technology where the reactors, moderated with heavy water, could be loaded with natural uranium to be used without enrichment. Importing uranium was considered difficult given the strict U.S. export control of nuclear materials and equipment. ${ }^{7}$ The Swedish uranium reserves, although of low grade, had been deemed as one of the richest in the western world by American and British investigations shortly after the Second World War. ${ }^{8}$

In Department 1 at FOA, the question of uranium production was tackled at an early stage. In October 1945, the Geological Survey of Sweden (SGU) had compiled a list of possible sources of uranium in Sweden. Groups were set up at FOA to conduct further research on the issue. Collaboration was initiated with several Swedish companies and research institutions to look into the possibilities of producing uranium (the companies Boliden Gruv AB, Svenska Skifferolje AB, Wargöns AB), The Royal Institute of Technology (KTH), Chalmers University of Technology and the Universities of Uppsala and Lund. ${ }^{9}$

In December 1945, the head of Department 1 at FOA, Gustaf Ljunggren, presented a proposal that led the way for the entire Swedish nuclear weapons program. In Ljunggren's opinion, Sweden should do the same as the United States-but the other way around. In the United States, civilian exploitation of nuclear energy was a "spin-off" of the nuclear weapons program, in which plutonium production held a central position. Ljunggren's view took the opposite approach and argued that the main aim should be the generation of nuclear energy, with plutonium production, which would make possible the manufacture of nuclear weapons as a side-effect. What Ljunggren was suggesting was to try and accommodate nuclear weapons production in the framework of civilian nuclear power. ${ }^{10}$

Several studies were done at the beginning of 1946 , such as how to start nuclear fission in a nuclear explosive device and how best to produce heavy water. ${ }^{11}$ During the same period, a special section was established for nuclear physics investigations at Department 2 under Sigvard Eklund, who later became the second Secretary General of the International Atomic Energy Agency (IAEA) between 1961 and 1981. During the fiscal year 1947-48 there was a further expansion of activities. New services were established and a number of studies were started. One study developed different methods for the separation of plutonium but the general purpose was to create a bank of knowledge in the field of plutonium chemistry. ${ }^{12}$

In 1947, AC issued a report that led to the formation of the company $\mathrm{AB}$ Atomenergi (AE), which was 57 percent government owned. The company was founded with the purpose of developing civilian nuclear power. The rest of the shares were split among 24 different Swedish companies belonging mainly to the energy, mining, steel and engineering industries. ${ }^{13}$ The members of the Atomic committee were also represented on the board of AE. A close 
collaboration between FOA and AE was initiated in order to work out technical and economic estimates for possible production of weapon-grade plutonium.

In February 1948, the Chief of the Defense Staff commissioned FOA to investigate nuclear weapons manufacture for the Swedish Defense Forces. The assignment included time schedules and cost estimates for the manufacture of nuclear weapons. ${ }^{14}$ The study was completed in three months and concluded that plutonium would be preferable to uranium-235 for use as nuclear material in explosive devices, and that it was too complicated and costly to produce highly enriched uranium. Therefore, a reactor would have to be built, and the reactor of choice would be fuelled with natural uranium with graphite as the moderator. According to the study:

... a working hypothesis is that the needed amount of uranium is between 500 to 1000 tons, and the needed graphite a couple of thousand tons, which would in all probability give the correct size. Such a reactor would have to perform the theoretically calculated output around 0.5-1.5 million KW..$^{15}$

This was considered sufficient for the production of 5-10 nuclear-explosive devices a year. It should be noted, though, that the analysis was based on technical data that are no longer considered accurate. According to the 1948 estimates, the amount of plutonium needed in a nuclear device was between 36-72 $\mathrm{kg}$, a figure understood only five years later to be too high by a factor of five or greater. ${ }^{16}$ If plutonium production such as that envisaged were to succeed at all, a large reactor would have to be built. A prerequisite for such a complex construction was that an experimental reactor would first be operated to determine how best to construct the main reactor (it might even be necessary to build an intermediate experimental reactor in order for a project of this magnitude to succeed, according to the authors of the report). ${ }^{17} \mathrm{~A}$ further prerequisite for the program outlined was access to nuclear materials, especially uranium and the required quantity of graphite. ${ }^{18}$ According to the study, it would take about eight years, probably longer, to produce a nuclear weapon once the equipment was in place. ${ }^{19}$ FOA estimated that this program would cost SEK 450 million, $\$ 1$ billion (2008\$), this did not include the costs of the build-up time of three to four years. The time schedule assumed that the required manpower would be available, that it would be possible to obtain the required nuclear materials, and that the reactors could be built as planned.

In 1949, a more extensive collaboration agreement was concluded dividing continued research and development work between FOA and $\mathrm{AE}^{20}$ In general terms, the agreement specified that FOA should be responsible for the overall nuclear weapons research, and specifically, in charge of the construction of a nuclear device and the studies of its effects. It was AE's responsibility to deliver basic information on the possible production of weapon-grade plutonium and to investigate the possibilities of production or procurement of heavy water without inspections by the supplying country. AE was also to build 


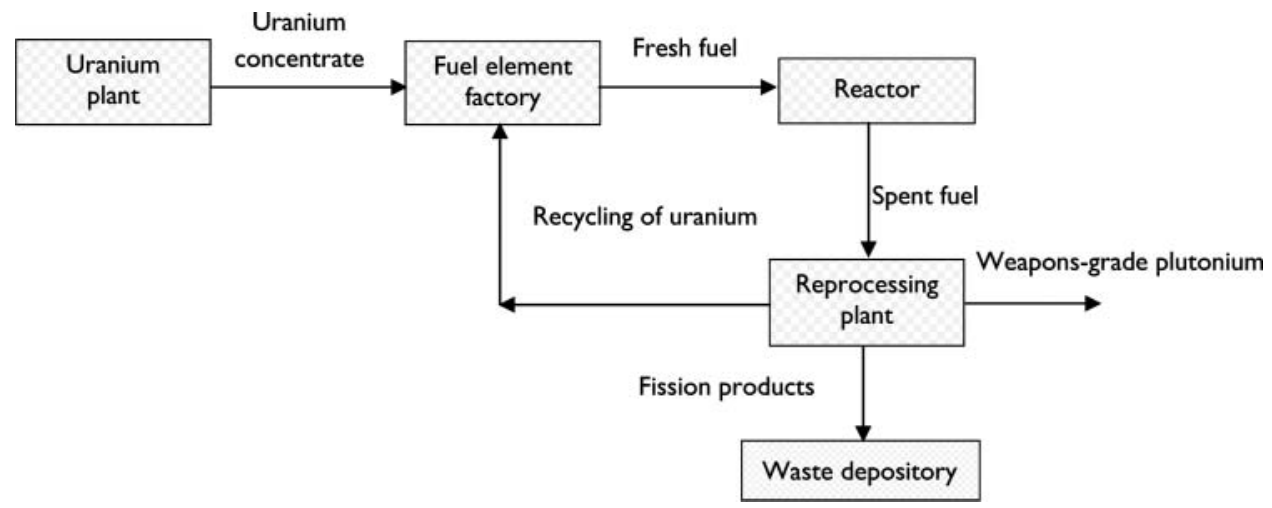

Figure 1: This figure describes in a simplified form how the co-operation between FOA and $A E$ was planned in a possible manufacture of nuclear weapons. AE was responsible for the production of uranium and fuel elements, the procurement of inspection-free heavy water and the design of reactors and a reprocessing plant in order to enable a production of weapons-grade plutonium. AE's responsibility extended to the point where weapons grade plutonium was produced. Further steps, until the nuclear weapons were manufactured, were FOA's responsibility.

reactors and a reprocessing plant capable of producing weapon-grade plutonium if a decision to do so was later made. In other words, the civil nuclear energy program should be designed in such a way that it could include the manufacture of nuclear weapons (Figure 1).

The division of responsibilities was not meant to draw a clear line between civilian and military activities. The division of work was instead made in order to economize on the limited resources of the country. ${ }^{21}$ Also, the cooperation between the $\mathrm{AE}$ and the Military can be understood in terms of developing new expertise.

It is important to stress that $\mathrm{AE}$ intended to produce plutonium even if Sweden decided not to manufacture nuclear weapons (except that the plutonium so produced would not be of weapon-grade quality). Although the basic technique of producing plutonium is the same for both military and civilian use, the plutonium to be used in a nuclear weapons device ideally contains 93 percent or more of plutonium $239 .{ }^{22}$ In order to produce plutonium of this weapons-grade quality, special re-fueling arrangements are required to keep the fuel burn-up low. It is noteworthy that the plutonium research at FOA and AE were complementary. FOA, for example, was especially interested in plutonium in the metallic form suitable for use in a nuclear weapon, while the $\mathrm{AE}$ focused on developing methods to separate plutonium from uranium and fission products (reprocessing) in order to allow the plutonium to be used as fuel in the reactors (plutonium recycling). This procedure would enable a more efficient use of the natural uranium. 


\section{COOPERATION WITH OTHER STATES}

Sweden looked to cooperate with other states in the field of nuclear research during this first phase. In the years following World War II, Swedish scientists sought contacts with the most-developed nuclear country in the world, the United States. The U.S. policy towards Sweden during the period 1945-1952 can be characterized by two objectives. First, to discourage the Swedes from exploiting their uranium, especially for military aims. Second, to prevent Sweden from acquiring highly enriched uranium, technical know-how, and advanced equipment that could be used in the production of nuclear weapons. Between 1945 and 1948, U.S. policy was very firm and restrictive. The United States Atomic Energy Commission (AEC) issued licenses for use of these products within the United States and for export to other countries. ${ }^{23}$ However, not all equipment and nuclear material were subject to export bans. In certain areas, friendly states could be assisted with research devoted to civilian nuclear energy. This restrictive policy had its price. During the spring and summer of 1949, several diplomatic reports from the U.S. embassy in Sweden described how Swedish nuclear scientists were looking for nuclear cooperation from the United Kingdom. For example, rumors circulated that the Swedish chemist, The Swedberg, Nobel Prize winner in chemistry, had been in contact with British scientists in order to get access to important research information and nuclear material. In addition, FOA and AE had sought to purchase heavy water in Norway, and Sweden had initiated cooperation with the French nuclear science establishment in the planning of the construction of Sweden's first reactor. $^{24}$

\section{THE PERIOD 1953-1959}

It would take an additional five years before the next major FOA study would be ready. ${ }^{25}$ The assignment from FOA had gone to Sigvard Eklund, the head of research at $\mathrm{AB}$ Atomenergi. The new FOA study concluded that the 1948 study was correct in assuming that plutonium was preferable to uranium-235 in the pathway to explosive nuclear devices. In the production of plutonium, the 1953 study concluded, however, that heavy water was preferable to graphite as a moderator.

Another change was that each nuclear explosive device had to be loaded with 8-15 kg of plutonium, far less than the calculated 36 to $72 \mathrm{~kg}$ in the 1948 study. With this new calculation, the target plutonium production figure was set at between $30-80 \mathrm{~kg}$ per year. The 1953 study presented two production alternatives. Alternative I considered the production of 1-3 nuclear explosive devices per year with a reactor capacity of 75 megawatt thermal (MWt). Alternative II envisioned the production of 3-5 nuclear explosive devices per year with a reactor capacity of $150 \mathrm{MWt}$ (Table 1). In this case two reactors would have to 
Table 1: The alternatives proposed in the studies for plutonium. Source: Swedish National Defence Research Establishment, "Preliminär utredning av betingelserna för framställning av atombomber i Sverige" (Preliminary investigation of the conditions for the production of atomic bombs in Sweden), 1953-03-05, H 4011-2092.

\begin{tabular}{llccc}
$\begin{array}{l}\text { Annual } \\
\text { production of } \\
\text { nuclear } \\
\text { devices }\end{array}$ & $\begin{array}{c}\text { Reactor } \\
\text { output } \\
(\mathrm{MW})\end{array}$ & $\begin{array}{c}\text { Annual } \\
\text { production of } \\
\text { plutonium } \\
(\mathrm{kg})\end{array}$ & $\begin{array}{c}\text { Amount of } \\
\text { plutonium in } \\
\text { each device } \\
(\mathrm{kg})\end{array}$ & $\begin{array}{c}\text { Reactor ready } \\
\text { for plutonium } \\
\text { production } \\
\text { (year) }\end{array}$ \\
\hline $1-3$ & Alt. 175 & 33 & 11 & 1960 \\
$3-5$ & Alt. II $2 \times 75$ & 55 & 11 & 1963 \\
\hline
\end{tabular}

be built, since, as far as was known, no reactor moderated with heavy water with a higher rating than $75 \mathrm{MWt}$ had been built anywhere in the world.

The intention was to use domestic uranium. AE had experimental production running and expected soon to start factory production of five tons of uranium per year. According to the report, it would be possible to double production after a few years. Converting the raw uranium concentrate into metallic uranium was a technically demanding process. Despite these difficulties Eklund felt that the time schedule could be met.

Heavy water could preferably be imported from Norway, the head of research at AE asserted in the 1953 FOA study. Norwegian production was 7 tons per year, but it was estimated that this could be increased to 15 tons. This meant that the amount required for Alternative I could be met from Norway in three years, and the maximum amount in Alternative II in six years. However, there were no guarantees that Norway would meet the Swedish requirements, which appeared to argue for more secure but also more time-consuming domestic production. ${ }^{26}$

If Alternative I were selected, a first reactor capable of producing weaponsgrade plutonium could be ready by 1960 . This would require the program to start at the beginning of fiscal year 1954-55. To achieve this required a one-off cost of SEK 240 million, $\$ 400$ million (2008\$) and an annual cost of SEK 26 million, $\$ 43$ million (2008\$).

If Alternative II were selected, it was estimated that a second reactor could be ready in 1963 . The estimated cost was SEK 378 million, $\$ 632$ million (2008\$) and the annual cost SEK 41 million, $\$ 51$ million (2008\$). For this project to succeed, an organization of at least 500 people would be needed.

\section{THE SWEDISH NUCLEAR-WEAPONS DEBATE STARTS}

Plans for Swedish nuclear weapon development began to be discussed openly around the mid 1950s. Earlier it had been a question confined to a small 
circle of politicians, military officers and scientists. A serious debate started, however, following a study by the supreme commander presented in 1954. In it he suggested that Sweden obtain nuclear weapons in order to uphold its non-aligned policy. ${ }^{27}$ The first parliamentary debate on nuclear weapon was held in May 1954, shortly after the first U.S. hydrogen bomb test. In the debate, Prime Minister Tage Erlander acknowledged that Sweden was conducting research on how to protect itself from nuclear weapons. However, he did not openly admit that FOA was also conducting research on possible Swedish nuclear weapons production. Erlander also said, in light of the U.S. hydrogen bomb test that he was hoping for international agreements on disarmament to be reached at the United Nations. ${ }^{28}$

In 1954, Sweden's first reactor R-1 went into operation, located 15 meters down a rock cavern at the Royal Institute of Technology in the central part of Stockholm (this was long before Three-Mile Island and Chernobyl). The reactor was not, however, loaded with uranium produced in Sweden, as such production of industry scale had not yet been started. Instead, AE had borrowed three tons of uranium from the French Commissariat á l'Energie Atomique (CEA). It was decided that the reactor should be moderated with heavy water (five tons were imported from Norway) even though graphite was also considered to be technically possible. The choice of heavy water was natural because this particular technology demanded less uranium. ${ }^{29}$ The head of the physics department, Sigvard Eklund, was in charge of the reactor project. Eklund used his international network contacts, particularly with the French, in the planning and construction of R-1. The American reactor CP-3 in Chicago served as a model for the first reactor and had an output of $1 \mathrm{MWt} .{ }^{30} \mathrm{R}-1$ was mainly a training facility.

During 1954 and 1955, Department 1 at FOA put a large effort into working out plans and cost calculations for the separation of plutonium. ${ }^{31}$ In a proposal for a work program, the researcher Jan Rydberg described the level of knowledge in Sweden concerning the isolation of plutonium. ${ }^{32}$ By studying foreign publications and through contacts between Swedish and foreign scientists, Rydberg was able to conclude that, "The information we in Sweden currently possess about the chemistry of plutonium, suitable separation methods and the appearance of the technical plant is exceptional."33

And one consequence of this was that Sweden was, “. . .in an entirely different knowledge situation than USA and Russia once were, and it is not unlikely that this also applies compared with Britain in 1946."34

This was followed by a time schedule showing how work should proceed in order to get plutonium production started. It was calculated that plutonium production would start in $1960 / 61$, provided that everything worked as planned. $^{35}$ 


\section{THE 1955 FOA STUDY}

At the end of November 1955, Torsten Magnusson's study was complete. ${ }^{36}$ Experts from universities and institutes of technology had been consulted as well as researchers and engineers from FOA and $\mathrm{AE}$.

The study is a good illustration of how rapidly development took place during this period. Swedish research constantly produced new knowledge, and the Geneva Conference had recently taken place, where the United States released previously classified information to collaborating countries under the "Atoms for Peace" program that was launched by President Eisenhower in 1953. The "Atoms for Peace" program was a gigantic global cooperation project to develop civilian nuclear energy in the world and simultaneously prevent the participating states from producing nuclear weapons. States which promised not to acquire nuclear weapons should be supported in order to develop their civilian nuclear energy. They could borrow or buy fissile material and nuclear equipment on attractive conditions regulated by bilateral cooperation agreements between, on one side the United States, or the Soviet Union and receiving states on the other. An outcome of this cooperation program was the creation of the IAEA in 1957. ${ }^{37}$

As was the case with the previous studies, the 1955 report considered the plutonium route to nuclear weapons to be a better alternative than uranium235. Firstly, reactors could be built which could be used for both nuclear weapons manufacture and energy production. Such a solution was considered to be financially more attractive. To this end, Sweden's scarce personnel resources in the nuclear energy field could be used more efficiently. Thirdly, it was also possible to make progress with civilian energy development, even if Sweden decided not to manufacture nuclear weapons.

In the 1955 report, the capacity to manufacture nuclear weapons had become clearer in comparison with the report released two years earlier. Now a nuclear weapon weighing only about $100 \mathrm{~kg}$ was being discussed, far lighter than FOA had previously envisaged. The devices, tactical nuclear weapons, were regarded as transportable and could be used in both missiles and torpedoes. They could even be fired from a gun according to the study. Each individual bomb would contain $6 \mathrm{~kg}$ of plutonium. The figures were not exact, and it was realized that they might have to be revised in the light of further research (Table 2). ${ }^{38}$

The study predicted it would take 8-10 years to produce the nuclear weapons, if the plans outlined above were achieved, possibly two years sooner if the plans were accelerated. The study also states that in order to achieve the set goals, several steps should be taken at once. For example, more intensive research into the design and operation of nuclear weapons would have to be started, initially at FOA with the involvement of external experts. 
Table 2: Comparison of different nuclear device alternatives. Source: "Utredning av betingelserna för framställning av atomvapen i Sverige" (Study of the conditions for the production of atomic weapons in Sweden) by Torsten Magnusson, 25 November 1955, Swedish National Defence Research Establishment, 87-H 163:1-21A.

\begin{tabular}{lcccc}
$\begin{array}{l}\text { Annual production } \\
\text { of nuclear } \\
\text { devices }\end{array}$ & $\begin{array}{c}\text { Reactor } \\
\text { output } \\
(\mathrm{MW})\end{array}$ & $\begin{array}{c}\text { Annual } \\
\text { production of } \\
\text { plutonium (kg) }\end{array}$ & $\begin{array}{c}\text { Amount of } \\
\text { plutonium in each } \\
\text { device (kg) }\end{array}$ & $\begin{array}{c}\text { Reactor ready } \\
\text { for plutonium } \\
\text { production (year) }\end{array}$ \\
\hline 3 & 55 & 18 & 6 & 1959 \\
5 & 90 & 30 & 6 & 1959 \\
8 & 150 & 50 & 6 & 1959 \\
\hline
\end{tabular}

The 1955 study established that it was technically possible from then on to produce a Swedish nuclear weapon, given access to plutonium. Technically the plutonium challenge had been met. It was equally clear to FOA what steps would have to be taken in a production process and approximately what the project as a whole would cost in the form of capital and scientific and technical expertise.

Following the Geneva Conference of 1955, Sweden was eager to gain access to formerly classified technical information and products previously banned from export in the United States. However, the policy of United States from the beginning was oriented to prevent Sweden from acquiring nuclear weapons. The Americans feared that if a peaceful and democratic country such as Sweden, which moreover enjoyed a stable security political situation, were to acquire nuclear weapons, the risk of further nuclear weapons proliferation in the world would increase substantially. The U.S. officials responsible for nuclear energy matters were strict on having all future cooperation go through the channels that had been decided upon by the AEC. The eagerness of the Swedish researchers and technicians to develop Swedish nuclear energy using highly enriched uranium imported from the United States put Washington in the position of being able to exploit Sweden's nuclear material related dependency. As Swedish nuclear research and development became more dependent on American assistance and collaboration, the more the United States could use its leverage to steer away Sweden from its nuclear weapons plans. ${ }^{39}$ For example, in 1956, the United States and Sweden signed an agreement on civilian nuclear energy cooperation. The two parties agreed to exchange information regarding the construction, operation and development of research reactors. The United States pledged to deliver up to 6 kilograms of uranium-235 in uranium enriched to a maximum of 20 percent, with possible further quantities to be delivered if they were deemed necessary by AEC for the continued effective operation of the reactors. The Swedish government committed itself to providing the $\mathrm{AEC}$ with information regarding nuclear energy developments in 
Sweden. The agreement forbade Sweden from using equipment and materials to develop nuclear weapons. ${ }^{40}$ The United States lowered the price of enriched uranium at the end of the $1950 \mathrm{~s}$, which reduced the fuel costs for running light water facilities. This enabled private companies in states such as Sweden to start investing in light water technology, since they did not need to spend fortunes on developing methods for enriching or processing uranium themselves. The light water technology was promoted as more economically favorable and reliable than the heavy water system. This action had constraining effects on the government controlled nuclear energy policy in Sweden.

\section{THE LAUNCHING OF THE "SWEDISH LINE"}

The ten years following the first decision to initiate nuclear-weapons research and the creation of the Atomic Commission in 1945 were dynamic, with many nuclear infrastructure development projects for Sweden. AC had worked out plans as to how the Swedish nuclear program should be designed. In addition, one reactor and several research facilities for uranium and heavy water production and plutonium research had been established. However, the Swedish parliament had not yet decided to launch the nuclear program. In 1956, the decision was taken in the Swedish parliament to carry out the heavy water program aimed at producing reactors loaded with natural uranium. The program was called "the Swedish line," and was one of the largest industrial projects in Swedish history. Under the supervision of the mainly government-owned AB Atomenergi, 5-6 reactors, uranium processing and fuel fabrication facilities were planned. ${ }^{41}$ In order to reach all of these goals, AE was designated to invest and allocate capital to promote education, research and development of a basic nuclear infrastructure, and to make sure that different sectors of Swedish society participated. Private companies would build reactors and other facilities, but the critical decisions would remain the government's responsibility. ${ }^{42}$

In May of 1957, the Supreme Commander gave FOA the task of carrying out a new study of the possibilities to produce nuclear weapons focused on the plutonium option. A political decision, yes or no to nuclear weapons, would soon have to be made and it was essential that the information used to make this decision be as broad as possible. ${ }^{43}$

The study should be conducted in two stages. The aim of the first stage was to produce a more general and approximate estimation of possible nuclear weapons manufacture before the end of the year. The second stage would contain more detailed results and, as the assignment states, "the necessary schematic design proposals." This stage (or at least the essential parts of it) should be completed no later than 1 June $1958 .^{44}$

In January 1958, AE completed a partial report on the choice of reactors for a Swedish nuclear weapons program. In the report, AE favored a separate reactor for the production of plutonium for weapons use only. Such a solution would 
be technically and economically preferable compared to a reactor for both civilian and military use. There were many reasons for this, according to AE. One of the main ones was that a dual-purpose reactor would have to undergo frequent fuel changes, which was a complication. In addition, such a reactor would give rise to a number of technical and scientific problems such as lower pressure and temperature. ${ }^{45}$ On 1 July 1958, AE issued its second report concerning the choice of reactors for the production of plutonium of weapons-grade quality. The report dealt with the manufacturing costs for weapons-grade plutonium for fuel elements canned in aluminium. Additionally, cost estimates were made for the reactor and reprocessing plant, the manufacture of metallic plutonium and waste disposal. ${ }^{46}$ Two reactors were of special interest in this respect: the Ågesta Nuclear Power Station south of Stockholm and Marviken close to the city of Norrköping. Ågesta Power Station went into operation in 1963. The reactor was a prototype facility with an output of $65 \mathrm{MWt}$, from which $55 \mathrm{MW}$ was used for heating the Stockholm suburb Farsta and 10 MW for electricity generation. The Ågesta Nuclear Power Station was closed down in 1974 for economic reasons. The Marviken power station was built but did not go into operation. The Marviken project was eventually abandoned in 1970.

\section{SWEDISH PARLIAMENT DECIDES NOT TO DECIDE ON NUCLEAR WEAPONS PROGRAM}

By 1958, Swedish nuclear-weapons research had reached a point where a political decision could be made. Two studies were presented to the parliament for consideration. One, known as the "device program," would be followed if Sweden chose to acquire nuclear weapons; the other, the protection program, would be implemented if parliament said no to nuclear weapons.

The device program did not differ greatly from the 1957 study. However, there were two significant changes. First, the United States and Great Britain had begun to publish data from experiments with fast reactors, which meant that less effort had to be channeled into that area of the activity. Second, it was decided that more work needed to be done on plutonium metallurgy.

It was calculated that $10 \mathrm{~kg}$ of plutonium could be ready in 1965, provided that plans were implemented in July 1959, a delay of two years compared with the 1957 study. A finished prototype of a Swedish nuclear weapon could see the light of day in 1966.

As the protection program states, it was intended to cover defense research for Sweden to be able to protect and defend itself against a nuclear enemy. The goal of this research was to obtain knowledge of an aggressor's nuclear weapons system so that the Swedish defense force could be configured in the best possible way. ${ }^{47}$ 
In the parliamentary debate that preceded the approval of the bill, international developments regarding nuclear weapons was the rationale for postponement. Sweden should study security policy and concurrently conduct protection research at the same time. This policy would ensure that Sweden would not lose ground if the international situation became more threatening and the policy analysis favored Swedish nuclear weapons. ${ }^{48}$

What effect did the growing political opposition against the nuclear weapons plans have on Prime Minister Erlander? The evidence indicates that he began to have doubts about equipping the Swedish military with nuclear weapons as early as 1957. Beginning on 1 January 1957, Sweden was seated on the U.N. Security Council, with membership on the committee charged with nuclear disarmament issues. As early as January, 1957, Sweden advanced a proposal for a nuclear test moratorium. Foreign Minister Undén worked energetically to promote international disarmament during the next few years, greatly influencing public opinion in Sweden and also Erlander himself. ${ }^{49}$ This is not to say that Erlander came out publicly against the acquisition of nuclear weapons, nor even within the inner circle of social democratic leaders. Erlander prioritized the achievement of broad political consensus on the nuclear weapons issue, which meant that the social democratic party would decide the matter together with the centrist and right-wing parties. With his middle position, Erlander encouraged grassroots opposition towards Swedish nuclear weapons, and this provided Undén and other skeptical politicians and others the opportunity to organize political grassroots campaigns against the idea. At the same time, Erlander worked to achieve a postponement of the crucial decision, thus allowing continued weapons related research. The concept of protection research served, for practical purposes, as a cover for the continuation of technical preparations. There were limits, however, in regard to how far FOA would be allowed to proceed with its preparatory work. Within the framework of the defense research that had been approved, what was allowed in practice? FOA would struggle with that question over next few years.

December 1959 saw the completion of an important report, which in many respects pointed the way to future protection research. The report was submitted by a committee of the Social Democratic Party Council for the study of the nuclear weapons issue. ${ }^{50}$ The young and promising politician, Olof Palme, who was to succeed Erlander as prime minister in 1969, was a member of the committee, and is presumed to have been the main author. Both proponents and opponents of Swedish nuclear weapons were represented in the group. In this respect, the committee membership reflected Erlander's strategy of allowing both sides to have a say on the issue. It can also be argued that Erlander had by now more or less changed his mind and was no longer in favor of acquiring nuclear weapons. With opponents mobilizing opposition towards the plans during the postponement period, it was assumed that public opinion was leaning more and more in the direction of a "no" to Swedish nuclear weapons. While allowing 
public debate and campaigns against the plans to continue unabated, Erlander was in a position to say to proponents of the plans that research would be allowed to continue but that, in the end, international developments in the area of nuclear nonproliferation would determine the decision for or against nuclear weapons acquisition. The study was far-reaching and discussed various technical solutions in relation to the possible production of nuclear weapons. Like Parliament in July 1958, the committee of the Social Democratic Party Council took the view that the future security political situation would determine whether or not Sweden should acquire nuclear weapons. The analysis concluded that Sweden had breathing room until at least the mid-1960s, when international developments would guide decision making. In the meantime, defense research should continue. It is clear from the report of the committee of the Social Democratic Party Council that it was difficult to draw a precise boundary between protection and design research. Nevertheless, the report specified that no design research aimed directly at the manufacture of nuclear weapons should be carried out. In addition, weapons-grade plutonium may not be used in the context of future protection research. However, in practice, FOA would carry out studies on design research and made cost calculations on the possible production of nuclear weapons in the coming years.

\section{THE PERIOD 1960-1968}

During 1960 and 1961, several studies were completed at AE relating to the cost and personnel requirements for the production of weapons-grade plutonium. One option was to produce plutonium using a dual-purpose reactor for weapons-grade production, i.e., within the civilian nuclear power program, or to use a strictly military production reactor with no connection to the civilian program. ${ }^{51}$ All the studies arrived at the same conclusion, namely that the costs would be drastically lower using only a military reactor. Against this backdrop, it is important to note that in the beginning of 1960s the light water reactor technology was introduced on the international market as an economically favorable and reliable reactor system compared to heavy-water technology. The main reason for this was the lowering of the prices of enriched uranium in the United States, which reduced the fuel costs for light water facilities.

Because of these changing prerequisites for heavy-water reactors which could in principle use domestic uranium, a study was carried out by the Atomic Commission's successor, the Delegation of Atomic Energy Issues (DFA), in 1959 , to analyze the prospects for the "Swedish line." The investigation concluded that Swedish production of uranium was estimated to cost 70 percent more than uranium imported from the United States. Some of the experts in DFA, who by and large represented industry, were in favor of importing 
uranium, even though it would imply restrictions in the form of foreign inspections. ${ }^{52}$ Private industry also saw real opportunities for light water technology in Sweden which would involve imports of low enriched uranium and presumably consequent restrictions on its uses.

Despite the attraction of light water reactor technology, a majority of the members of the DFA recommended that the "Swedish line" be continued to promote self-sufficiency. One argument was that investments had already been made in facilities and research such as AE's uranium production plant at Kvarntorp, which went into operation in 1953. Another argument was that Sweden should maintain its option to produce nuclear weapons. Reactors loaded with enriched uranium from United States (which would imply restrictions in the form of U.S. inspections) could not be used for production of weapon-grade plutonium. This was not officially expressed since the research on nuclear weapons was highly secret. Even though it was decided that the planned heavy water reactors R-3 in Ågesta and R-4 in Marviken should be built and loaded with domestic natural uranium, it was obvious that a conflict had arisen between private industry's incentives for low production costs and the government's intention to keep some freedom of action, including possible nuclear weapons manufacture. This conflict would grow during the following years.

During 1961, the Swedish military command was formulating of a new defense plan. The formerly strong consensus, within the military, in favor of equipping the Swedish defense forces with nuclear weapons was now beginning to disintegrate. There were several reasons for this new disunity. One was the competition among different branches of the armed services. The army and the navy feared that they would lose out in the struggle for budget appropriations; the air force was expected to be awarded the bulk of additional nuclear related budgetary resources since the nuclear weapons were primarily to be mounted on aircraft. But even within the air force there were growing doubts about the advantages of possessing nuclear weapons. The air force had other costly projects to defend, among them the development of a new fighter aircraft. If the nuclear weapons plans were realized, these important projects might be abandoned. Because of this intra-military disunity, the nuclear weapons issue was not dealt with specifically in the defense review ÖB62. Instead, the matter was delegated to a special, secret review board, the so-called Nuclear Device Group, a move that enabled the military command to maintain a united front. ${ }^{53}$

In February 1962, the Nuclear Device Group presented its findings. In the published report, the Group observed that the nuclear weapons doctrine of massive retaliation, which had been in force up to then, was no longer operative. The Kennedy administration had put forward new ideas about the importance of conventional weaponry in a possible future war. It was no longer deemed likely that nuclear weapons would be used for the purpose of causing 
massive devastation of enemy territory in the initial stages of a new war. Nuclear weapons would, on this view, be used on a smaller scale based on assessments of the immediate situation. This new doctrine would later be coined flexible response. The ÖB-62 report also advocated enhancement and expansion of Sweden's conventional military forces and capability, since an attack against Sweden would likely be carried out with conventional weaponry. The report maintained that Swedish nuclear weapons remained a viable option, but for practical purposes even the military was now discounting this possibility. ${ }^{54}$

For practical purposes, the report's findings implied a retreat from the military's previously maintained hard line, which said that Sweden's defense forces must be equipped with nuclear weapons in order to achieve the requisite strike capability and deterring capacity. Despite this apparent retreat, however, the report still underscored the importance of maintaining all available options and attention was still focused on the possible production of tactical weaponry. Against this background different solutions were discussed. If a pure weapons program were undertaken, production time would be shortened considerably. But since the intention was that a possible nuclear weapons program would be accommodated within the framework of civilian development work, it would take far longer. For this reason, the authors of the study proposed a gradual process of acquisition of nuclear weapons capability:

Such an approach would mean postponing a definitive decision until devices could be added to the organisation relatively quickly, but it assumes that all necessary measures are taken to prepare for rapid acquisition-including research into the construction of the necessary plant. These measures must not pre-empt the definitive decision, only facilitate the elaboration of a flexible security policy. However, this may mean exploiting the civilian atomic energy programme to a greater extent than would be economical from the point of view of pure acquisition. ${ }^{55}$

Previous reports had calculated that the first nuclear explosive device could be ready in 1966. But the delay in the civilian nuclear energy program had pushed this date back to 1972 . Admittedly, the lost time could be limited to two or three years, if inspection-free heavy water were to be ordered more or less immediately. Some design problems still remained unsolved. But the overall picture was sufficiently understood to allow the development of a warhead with a yield in the $5-50$ kiloton range.

Attention was still focused on tactical nuclear weaponry-there were plans for 100 such devices, the first of which could appear in 1972, unless steps were taken to accelerate the process. The Nuclear Device Group had the A-32 Lansen attack aircraft in mind when considering the choice of weapon carrier. The Lansen could easily be modified to carry nuclear bombs and missiles. The A-37 Viggen attack aircraft, production of which was planned to begin at the end of the 1960s, could be fitted with similar weapons. The report concluded 
that submarines could also be equipped with nuclear weapons, in the form of torpedoes.

The Marviken reactor was regarded as the best site for plutonium production. In time, however, this choice could give rise to problems with the United States. In light of developments in the civilian nuclear power field, it was likely that the first fuel loading at Marviken would probably consist of enriched uranium of U.S. origin. Enriched uranium was inexpensive in the United States, and Swedish industry would never have accepted the large investments needed for enriching natural domestic uranium. On the other hand, the use of U.S. uranium would mean accepting inspection requirements, which would prevent the uranium in question from being used for weapons purposes. Of course, subsequent fuel loadings could incorporate Swedish natural uranium, but the question of how the United States might react to such a step arose. ${ }^{56}$ Using Marviken depended on the availability of inspection-free heavy water:

We must therefore as soon as possible reach an agreement with Norway to import the necessary amount without conditions or decide to start the manufacture of Swedish heavy water.

Another precondition was that it should be possible to set up a reprocessing plant. The civilian nuclear energy program was not expected to need one before 1975. For this reason, continued planning should take into account the need to build a reprocessing plant to avoid further delays. The total costs of the planned nuclear weapons program for 100 devices were calculated for three options:

1. If a pure plutonium-producing reactor (single-use) were chosen, and if attack squadrons were used as weapon carriers, the cost would be SEK 1115 million, $\$ 1.4$ billion ( $2008 \$)$.

2. If the Marviken reactor (dual-use) were used to produce plutonium with aluminium-encased fuel elements, and if the weapon carriers were missiles, the cost would be SEK 1812 million, $\$ 2.3$ billion (2008 $\$$ ).

3. If the Marviken reactor (dual-use) with zircaloy-encased fuel elements were chosen, and attack squadrons, missiles and submarines were used as weapon carriers, the total cost would be SEK 1988 million, $\$ 2.5$ billion $(2008 \$)$.

If the program with 100 tactical nuclear weapons was carried out during the period 1965-1975, the total cost would be about 5 percent of the entire budget of the Swedish defense force. If a program were initiated in 1964/1965 with planned completion between 1979 and 1980, this would correspond to 2.7 percent of the entire military budget during this period. In the light of these figures, the report concluded that a nuclear weapon program could be managed within the framework of the budgets proposed in the Supreme Commander's 
defense study (ÖB 62), with no risk of significant reductions in other weapon systems.

At a meeting at the Chief of the defense staff, it emerged that, despite the recommendations of the nuclear device group, most of the indications were that Marviken should be loaded with enriched uranium, instead of natural uranium as planned. This was mainly for financial reasons, according to the memorandum of the meeting. And if this were to be done, the consequence would be that the enriched uranium would have to be imported from the United States, which in turn gave the United States the right of inspection. Consequently Marviken could not be used for nuclear weapons production. The reactor could in fact be loaded with natural uranium at a later date, but this would lead both to delays and to far higher costs. In addition, such a procedure might attract attention, since it could hardly be concealed. ${ }^{57}$

\section{POLICY TAKES A FIRM POSITION}

In parallel with the expanding nuclear cooperation between Sweden and the United States, a close collaboration in defense policy emerged between the two states during the $1950 \mathrm{~s}$. This cooperation was very sensitive for Sweden because of its non-alignment policy. In official communications during the Cold War, successive Swedish governments asserted that no military cooperation was taking place with either NATO or the United States. But research and official investigations carried out since the end of the cold war have revealed that Sweden in fact pursued far-reaching cooperation with the Western European powers and the United States ever since the late 1940s. In 1952 and 1962, respectively, two agreements were signed between Sweden and the United States regarding cooperation in the area of Military technology. For example, the Swedish army bought and manufactured under license several U.S. robot systems, such as the Falcon, the Sidewinder and the Hawk. The increasingly close cooperation between the two states in the area of military technology led to the use of formal and, primarily, informal channels to communicate what was permissible for Sweden if it wished to see this cooperation continue. ${ }^{58}$ The more Sweden's nuclear related R\&D became dependent on U.S. military assistance and collaboration, the more the United States could use its superiority to steer Sweden away from its nuclear weapons plans. This factor is also probably decisive in changing the Swedish military command's perspective on the plans to equipping the Swedish defense with nuclear weapons.

On April 6, 1960, the U.S. National Security Council (NSC) decided what policy should be pursued towards Sweden's nuclear weapons plans. ${ }^{59}$ In the NSC policy guidance from 1960, it is clear that the Swedish neutral position is accepted by the United States and is even deemed a positive factor for the United States and NATO: 
Under the present circumstances, Sweden's membership in NATO is not necessary to Western defense. It would contribute to the over-all defensive strength of the Western powers for Sweden to modernize its defense posture and to establish in Sweden an early warning air control and advanced weapons systems (without nuclear warheads) which are compatible with and complementary to those planned for installation in the territory of neighboring U.S. allies.

In other words, the United States wished to assist Sweden in building up a stronger conventional defense capability and thereby integrating Sweden into the NATO framework. Against this backdrop, it would be unwise for Sweden to exhaust its limited financial and technical resources in order to acquire nuclear weapons since such weapons already existed within NATO. Therefore the NSC now took a firm position on the Swedish inquires about the purchase or other possible use of U.S. nuclear warheads, while also discouraging the Swedes from manufacturing their own nuclear weapons:

... do not provide nuclear warheads; and discourage Sweden from producing its own nuclear weapons.

Even though a decision not to provide the Swedes with U.S. warheads might lead to more serious plans to manufacture nuclear weapons in Sweden, it was not deemed likely since such a nuclear weapons program would be exceedingly costly for a small country like Sweden, the NSC concluded. Furthermore, such a Swedish weapons program would be dependent on American goodwill and assistance, i.e., certain materials and advanced equipment would have to be imported from the United States.

\section{THE NUCLEAR WEAPONS OPTION IS ABANDONED}

Throughout the 1960s, FOA and AE continued to explore various reactor options, including those that would produce weapon-grade plutonium. And, in parallel, from the mid to the late 1960s, the United States, Soviet Union, and other nuclear weapon states were developing and eventually negotiating an NPT, which binds non-weapon states to remain non-weapon in the future.

The conflict between Swedish civilian and military objectives became more pronounced as economic realities arose. In 1965, the first Swedish order was placed for a commercial power reactor station based on light water technology. ASEA should manufacture a light water reactor with an output of 400 MW to the planned nuclear power plant Oskarshamn 1, belonging to the Oskarshamnsverkens Kraftgrupp AB (a private consortium). The following year the Swedish government signed an agreement with the United States concerning a purchase of enriched uranium. The agreement was to be in force for 30 years, and accordingly it was in effect until its expiration in 1996. This meant that a strictly military reactor program has to be built if Sweden wanted to 
produce nuclear weapons. ${ }^{60}$ For this reason the military leadership felt it would be forced to pursue a policy of phased procurement, if the policy of freedom of action was to be sustained. During the late autumn of 1965, the chief of defense staff requested FOA to investigate alternative research plans in order to carry out such phased procurement. ${ }^{61}$ FOA worked out a plan in the budget proposals for 1966, which enabled it to meet these requirements. The government rejected this policy, however, in its 1966 plans, and thus the Swedish nuclear weapons planning was, in practice, terminated. ${ }^{62}$

A drastic reduction of FOA's nuclear weapons research activity followed. AE's planning for uranium production at Ranstad ceased, as did plans for a reprocessing plant on a site already purchased in Bohuslän on the west coast. It was stated in the government's defense proposals for 1968 that acquiring nuclear weapons was not in line with Sweden's interests. Parliament agreed, and thus the policy of freedom of action was removed from the field of security activities.

It was with this background that the government decided in August 1968 to sign the NPT. The government-controlled AB Atomenergi (AE), which by and large dominated "the Swedish line," was also dissolved in 1968 and its resources were transferred to the new private company ASEA-ATOM (owned by the Swedish multinational corporation ASEA). As a consequence, "the Swedish line" and its ambition to reach independence in the nuclear energy field was now abolished and replaced by the light water reactor technology. Swedish nuclear weapons aspirations were now definitely dead and buried.

How far had FOA progressed in its research by the time the nuclear weapons plans were abandoned? In principle, and from a technical point of view, FOA knew exactly what to do and had the reactors and materials to do it. However, there were also some important ingredients missing from a functioning production chain, namely a reprocessing facility and more inspectionfree heavy water. Technically it would have been possible to manufacture a single nuclear explosive device given sufficient plutonium of weapons-grade quality, but a single device would not have constituted a full weapons program. By all accounts the planned program would have included about 100 nuclear warheads. Within the framework of such a large-scale serial production program, it would probably have taken Sweden several years to manufacture its first nuclear device.

\section{CONCLUSIONS}

The FOA performed five main studies on the manufacture of nuclear weapons between 1945 and 1968, the year when the Swedish government signed the NPT effectively ending Sweden's nuclear weapon program. These technological research studies were completed in 1948, 1953, 1955, 1957 and 1965, 
which together expanded the Swedish know-how to produce a bomb. It can be argued that Sweden, in principle, already had the technical knowledge and components to produce nuclear weapons by the mid-1950s, if the state had access to enough plutonium, though research in later years suggested that this may have been an overly optimistic view. This research pointed to technical problems with arranging the production of nuclear weapons according to the guidelines suggested in the 1955 study. Nevertheless, Sweden by the mid 1950s had already completed intensive research aimed directly at producing nuclear weapons and had ample scientific and technical expertise. It had, as well, a working research reactor and sufficient uranium resources to sustain a limited weapon program.

Do the activities between 1945 and 1968 constitute a nuclear weapons program? Alternatively, were all these activities just part of plans carried out on a theoretical level, since a decision was never taken by the government and the parliament to go ahead? From a strict, formal point of view, they were only plans, because no decision to start a serial production of nuclear weapons was taken. In this strict, formal interpretation, the Swedish case only covered research, planning and experimental evaluations. But if we take into account the whole concept to place the military manufacture within the framework of civilian development of nuclear energy, it could be argued that it was indeed a program. A uranium plant and a fuel fabrication facility were already in operation, at least two reactors capable of production of weapons-grade plutonium were built (Ågesta and Marviken), Sweden had about 50 tons of inspection-free heavy water at its disposal (an additional 50 tons were needed), ${ }^{63}$ and several arrangements to equip Swedish-built jet attack aircrafts with nuclear weapons had been conducted.

So, how important were the technical reasons for the Swedish cessation of nuclear weapons plans? This question has to be answered in the context of other possible reasons.

It became increasingly clear to policy makers that integration between civilian and military goals would be difficult and costly. This made possible the mobilization of political opposition against nuclear weapons, with public opinion and parliamentary discussions moving gradually in the direction of rejecting nuclear weapons. In the beginning of the 1950s, Prime Minister Tage Erlander and many leading Social Democrats were in favor of these nuclear plans, and so was the majority of Swedes according to polls. However, in the 1960s Prime Minister Erlander and many in the Social Democratic power elite had changed their minds, and had become increasingly skeptical about the wisdom of equipping the Swedish defense force with nuclear weapons. The polls from the 1960s also reflected a rising public opposition to nuclear weapons. In addition, a grass-root movement against the weapons plans was founded in the end of 1950s, "Aktionsgruppen mot svenska atomvapen" (the action group 
against Swedish atomic bombs), and became very successful in its struggle against Swedish nuclear weapon plans. ${ }^{64}$

Secondly, the international disarmament discussions and the nonproliferation norms emerging from the mid-1950s onwards and leading in 1968 to the NPT also affected the Swedish public debate and strengthened the arguments against Swedish nuclear weapons acquisition. From the mid-1950s, and especially during the $1960 \mathrm{~s}$, Sweden became increasingly involved in the international efforts to halt the spread of nuclear weapons. In the United Nations, Sweden advanced proposals aimed at creating nuclear weapon free zones and achieving nuclear disarmament. This policy meant that the technical progress in the direction of making domestic production of nuclear weapons feasible was to be weighed against international developments in the nuclear disarmament area. In plain language this meant that if the international negotiations were unsuccessful, the policy of postponing the decision would no longer be followed.

Thirdly, as a consequence of integrating the production of nuclear weapons within the civilian nuclear energy program, Sweden, despite contrary intentions, grew dependent on U.S. technology. This technological dependence vis-àvis the United States increased over the years and provided the United States with leverage to dissuade Sweden from using its civilian program for producing weapon-grade plutonium.

\section{REFERENCES}

1. In Sweden, an article in the magazine $N y$ Teknik in the mid-1980s gave rise to intense discussion since the author, Christer Larsson, stated that the Swedish public, parliament, and even certain members of the cabinet had been deceived by an inner circle of decision-makers. According to Larsson, this inner circle, composed of ministers, senior officers, and scientists, conducted a secret nuclear weapons program covering the full spectrum of preparations. See Christer Larsson, "Historien om en svensk atombomb 1945-1972" Ny Teknik No. 3, 1985. As a consequence, the government commissioned an inquiry, which published a report, Swedish Ministry of Defence, Svensk kärnvapenforskning 1945-1972, in 1987 (Stockholm, 1987). The report concluded that the research carried out never overstepped the limits imposed by parliament and the government. In Nov. 1994, the Swedish nuclear weapons plans were the subject of an article in the Washington Post, which stated that Sweden's will to remain a non-nuclear weapon state was questioned, since parts of the ambitious research program were still in operation. See Steve Coll, "Neutral Sweden Quietly Keeps Nuclear Option Open," Washington Post, 25 November 1994.

2. Per Ahlmark, Den svenska atomvapendebatten (Stockholm: Aldus/Bonnier 1965); Wilhelm Agrell, Alliansfrihet eller atombomber-Kontinuitet eller förändring $i$ svensk försvarsdoktrin 1945-1982 (Stockholm: Liber förlag, 1985); Paul Cole, "Atomic Bombast: Nucler Weapons Decisionmaking in Sweden 1945-1972," occasional paper no. 26, Washington, D.C: Henry L. Stimson Center, 1996; Jerome Henry Garris, Sweden and the Spread of Nuclear Weapons (unpublished PhD thesis, University of Calfornia, 1972); Anna-Greta Hoadley Nilsson, Atomvapnet som partiproblem (Stockholm: Almqvist \& Wiksell International, 1989); Thomas Jonter, Sverige, USA och kärnenergin. Framväxten av en svensk kärnämneskontroll 1945-1995, SKI Report 99:21 (Stockholm: Swedish Nuclear Power Inspectorate, 1999), May 1999; Sweden and the Bomb. The 
Swedish Plans to Acquire Nuclear Weapons, 1945-1972, SKI Report 01:33(Stockholm: Swedish Nuclear Power Inspectorate, 2001), Sept., 2001; Nuclear Weapons Research in Sweden. Co-operation Between Civilian and Military Research, 1947-1972, SKI Report 02:18, (Stockholm: Swedish Nuclear Power Inspectorate, 2002), May, 2002; Mitchell Reiss, Without the Bomb: The Politics of Nuclear Nonproliferation (New York: Columbia University Press, 1988); Björn von Sydow, Kan vi lita på politikerna? Offentlig och intern politik $i$ socialdemokratins ledning 1955-1960 (Stockholm: Tiden, 1978).

3. Anders Fröman, "Kärnvapenforskning," in Försvarets forskningsanstalt 1945-1995 (Stockholm: Försvarets forskningsanstalt, 1995), 162.

4. Tage Erlander, 1955-1960 (Stockholm: Tiden, 1976), 75 et passim.

5. Sigfrid Leijonhufvud, (parantes? En historia om svensk kärnkraft Västerås: ABB Atom, 1994), 18.

6. Karl-Erik Larsson, "Kärnkraftens historia i Sverige," Kosmos (1987), 64, 125-126.

7. Gunnar Skogmar, Atompolitik: sambandet mellan militärt och civilt utnyttjande av atomenergin $i$ amerikansk utrikespolitik 1945-1973 (Lund: Lund Political Studies, 1979).

8. Gunnar Skogmar, De nya malmfälten. Det svenska uranet och inledningen till efterkrigstidens neutralitetspolitik, Research programme Sverige under kalla kriget, Arbetsrapport nr 3 (Göteborg: Statsvetenskapliga institutionen, 1997).

9. Report on the operations at the Swedish National Defence Research Institute department 1 . From 1/4 1945 to 30/6 1946, the archive of Swedish National Defence Research Institute (From now on called "the FOA archive"), H 188/05.

10. The basis of the report by Swedish Ministry Defense, Svensk kärnvapenforskning 1945-1972 (Swedish Nuclear Weapons Research, 1945-1972), (basis), 7.

11. A memo dated 7 January 1946 described various methods of producing heavy water. Lund researcher Lamek Hulthén, who wrote the report, thought that it would be possible to develop Ljungaverket's electrolysis operation to reach a higher level of production. Although the capital cost would be great and it would take a long time to set up the plant, in purely technical terms the problem was solved, so it was claimed.

12. "Verksamhetsberättelse för budgetåret 1947/48" (in Swedish), the FOA archive, H $158 / 48$.

13. Stefan Lindström, I hela nationens tacksamhet. Svensk forskningspolitik på atomenergiområdet 1945-1956 (Stockholm: Stockholm Studies in Politics, 1991), 92.

14. "Inkommande handlingar1948 E III a" (in Swedish), the FOA archive, Volume 4, H 35.

15. Ibid.

16. "Utredning av betingelserna för framställning av atomvapen i Sverige" (in Swedish), by Torsten Magnusson, the FOA archive, 25 November 1955, 87-H 163:1-21A.

17. "Utgående handlingar 1948 B IV" (in Swedish), the FOA archive, Volume 4, H $35: 2$.

18. High-purity graphite was being tested by the companies ASEA and Skandinaviska grafitindustriaktiebolaget (the Scandinavian Grafite company).

19. It was estimated that it would take two years to set up the mining and production operation, five to ten years to produce 500 to 1000 tons of uranium at a production capacity of 100 tons per year, and one year to produce bombs ready for use. 
20. “Överenskommelse", the FOA archive, H 129, 30 October 1950, FOA.

21. Lindström 1991, 92-93.

22. About the practical implications for different so-called "Direct-usable Fissile Materials," see Maerli, Morten Bremer, "Managing Excess Nuclear materials in Russia," pp. 49-51, in Nuclear Weapons into the 21st Century. Current Trends and Future Prospects. (Ed. Joachim Krause and Andreas Wenger). Studies of Contemporary History and Security Policy, vol 8 (Zürich: Center for Security Studies, 2001).

23. Skogmar 1979, 30.

24. Jonter 1999, 18.

25. "Preliminär utredning av betingelserna för framställning av atombomber i Sverige" (in Swedish), the FOA archive, 5 March 1953, H 2068-2092.

26. It is interesting to note that Israel was considering the same approach. During the 1950s, Norway and Israel were negotiating the sale of heavy water for the Israeli Dimona reactor. The agreement signed in 1959 meant that a big step had been taken toward producing Israeli nuclear weapons. See Avner Cohen, Israel and the Bomb (New York: Columbia University Press, 1998), 1, 33-34, 60-62, 83, 87.

27. Alltjämt starkt försvar; riktlinjer och kostnader Stockholm (Stockholm: Centralförbundet folk och försvar, 1954).

28. Lindsröm 1991, 161.

29. Svensk atomenergipolitik. Motiv och riktlinjer för statens insatser på atomenergiområdet 1947-1970 (Stockholm: Industridepartementet, 1970).

30. Maja Fjæstad, Sveriges första kärnreaktor - från teknisk prototyp till vetenskapligt instrument, SKI-rapport 01:1, 15 (Stockholm: Swedish Nuclear Power Inspectorate, 2001).

31. "Kostnadsberäkning av anläggning för isolering av plutonium" (in Swedish) by Jan Rydberg and Sten Mogensen, 28 January 1954, the FOA archive, H 4091; "Tillägg till Kostnadsberäkning av anläggning för isolering av plutonium" (in Swedish) by Jan Rydberg, 30 April 1954, the FOA archive, H 4092; "PM angående arbeten med plutonium inom sektionen för kärnkemi" (in Swedish), 13 February 1955, the FOA archive, H 4017; "Kostnadsberäkning av anläggning för isolering av plutonium" (in Swedish), by Jan Rydberg, 20 June 1955, the FOA archive, H 2246.

32. "Frågor av betydelse för isolering av plutonium för atombomber; förslag till arbetsprogram. (in Swedish)" by Jan Rydberg, 27 January 1955, the FOA archive, H 4140.

33. Ibid.

34. Ibid.

35. Ibid.

36. "Utredning av betingelserna för framställning av atomvapen i Sverige" (in Swedish) by Torsten Magnusson, 25 November 1955, Swedish National Defence Research Institute, the FOA archive, 87-H 163:1-21A.

37. About the "Atoms for Peace" cooperation and the creation of IAEA, see David Fisher, History of the International Atomic Energy Agency: The First Forty Years. IAEA (Vienna: IAEA 1997).

38. Up to the summer of 1955 the expectation was that the bombs would have to contain at least $10 \mathrm{~kg}$ of plutonium (for example, the 1953 study calculated with 11 kg. of plutonium in every device). At the Geneva conference, certain calculations were released concerning the critical mass of a device that meant that the Swedish National 
Defence Research Establishment's calculations could be heavily revised.

39. About the U.S.-Swedish nuclear cooperation, see Thomas Jonter, "The United States and the Swedish Plans to Build the Bomb, 1945-1968." Paper presented at the Security Assurances Workshop, Cheyenne Mountain Resort, 13-14 August, 2009, hosted by Center for Contemporary Conflict, Naval Postgraduate School, Monterey, California.

40. “Sveriges överenskommelser med främmande makter", SÖ 1956:67-68, Stockholm 1956.

41. Lindström 1991, 92.

42. Maja Fjæstad and Thomas Jonter, "The Rise of the Nuclear System of Innovation in Sweden," Scandinavian Working Papers in Economics, KTH/CESIS Working Paper Series in Economics and Institutions of Innovation, no. 117, http://cesis.abe.kth.se/documents/WP117.pdf

43. "P.M. angående utredningsuppdrag betr. reaktorer för produktion av plutonium av vapenkvalitet" (in Swedish), the FOA archive, 5 July 1957, H 4050-2092.

44. Ibid.

45. "Rapport över Etapp 1 av utredningsuppdrag beträffande reaktorer för produktion av plutonium av vapenkvalitet" (in Swedish). Executive archive, Studsvik AB (formerly AB Atomenergi), 9 January1958.

46. "Rapport över Etapp 2:1 av utredningsuppdrag beträffande reaktorer för produktion av vapenkvalitet" (in Swedish), 1 July 1958. The report is still under secrecy classification. About the report in general, see Olof Forssberg study (basis), 91.

47. "Forskningsprogram avseende skydd och försvar mot atomvapen" (in Swedish), 4 July 1958, the FOA archive, H 4040-2092.

48. For a detailed discussion and analysis of the various lines of argument in the debate that followed, see Ahlmark 1965.

49. Nilsson Hodley 1989, 43.

50. Neutralitet Försvar Atomvapen (Stockholm, 1960).

51. "Rapport över Etapp III av utredningsuppdrag beträffande reaktorer för produktion av plutonium av vapenkvalitet" (in Swedish), 28 April 1960; Executive archive, Studsvik AB; "Tillägg till rapport över Etapp III av utredningsuppdrag beträffande reaktorer för produktion av plutonium av vapenkvalitet" (in Swedish), Executive archive, Studsvik AB, 17 November 1960; "En rapport över etapp IV beträffande val av reaktor för plutoniumtillverkning av vapenkvalitet" (in Swedish), The reports are still under secrecy classification, except the following report which is an open source: "Svensk plutoniumfabrik under 1960-talet" (in Swedish), Executive archive, Studsvik AB, 20 June 1960, H 4162-434; "Rapport över Etapp V av utredningsrapport beträffande reaktorer för produktion av plutonium av vapenkvalitet" (in Swedish), "Rapport över Etapp VI av utredningsrapport beträffande reaktorer för produktion av plutonium av vapenkvalitet" (in Swedish), Executive archive, Studsvik AB, 14 Septemebr 1961; "Rapport över Etapp VII av utredningsrapport beträffande reaktorer för produktion av plutonium av vapenkvalitet" (in Swedish), Executive archive, Studsvik $\mathrm{AB}, 12$ December 1962.

52. Jonter 1999, 23; Svensk atomenergipolitik 1970, 32. AK's responsibility was split into two functions: DFA was in charge of the control and delivery of licenses in the nuclear energy field, while the "Statens råd för atomforskning" was responsible for basic research. DFA was transformed into the Statens kärnkraftsinspektion (Swedish Nuclear Power Inspectorate) in 1974. 


\section{Jonter}

53. Wilhelm Agrell, Svenska förintelsevapen. Utvecklingen av kemiska och nukleära stridsmedel 1928-70 (Lund: Historiska media 2002, Lund), 281-287.

54. Agrell 1985, 237.

55. Ibid.

56. Ibid.

57. Svensk Kärnvapenforskning, 1945-1972 (basis), 145.

58. Two government commissions have investigated the Swedish-U.S. military technological cooperation during the Cold War: Om kriget kommit: förberedelser för mottagande av militärt bistånd 1949-1969. SOU 1994:11 (Stockholm: Fritzes offentliga publikationer, 1994) and Fred och säkerhet. Svensk säkerhetspolitik 1969-89, SOU 2002:108 (Stockholm: Fritzes offentliga publikationer, 2002).

59. "U.S. Policy toward Scandinavia (Denmark, Norway and Sweden)," April 6, 1960, RG 273, NSC 6006/1, box 51, NA.

60. Jonter 1999, 29-30.

61. Department 4, "Ingående handlingar och utgående handlingar 1965 F", Volume 62, the FOA archive, $\mathrm{H} 4222-5$.

62. Swedish Parliament ("Swedish Riksdag"), "Proposition 1961:1," Government Bill 1966:1 (in Swedish), Appendix 6, p. 188 et seq.

63. Svensk kärnvapenforskning 1945-1972 (basis), 145.

64. Nilsson Hoadley 1989; von Sydow 1978; Ahlmark 1965. 